\title{
Decentralization and Participatory Rural Development: A Literature Review
}

\author{
Muhammad Shakil Ahmad', Noraini Bt. Abu Talib
}

ABSTRACT

\begin{abstract}
Most of the developing nations are still struggling for efficient use of their resources. In order to overcome physical and administrative constraints of the development, it is necessary to transfer the power from the central government to local authorities. Distribution of power from improves the management of resources and community participation which is considered key to sustainable development. Advocates of decentralization argue that decentralized government is source to improve community participation in rural development. Decentralized government is considered more responsive towards local needs and development of poor peoples. There are many obstacles to expand the citizen participation in rural areas. There are many approaches for participatory development but all have to face the same challenges. Current paper highlights the literature about Decentralization and participatory rural development. Concept and modalities of Decentralization, dimensions of participation, types of rural participation and obstacles to participation are also the part of this paper.
\end{abstract}

KEY WORDS: $\quad$ decentralization, participatory rural development, sustainable development, literature review, rural development policy

JEL Classification: R500, R590

${ }^{1}$ Technology University of Malaysia, Malaysia

\section{Introduction}

International donor agencies acknowledged decentralization as a platform to improve citizen participation and service delivery. Decentralization is a source for bottom up participatory development, thus improving local governance resulting poverty reduction in rural areas. The whole purpose of development is being redefined so as to bring people to the central stage. Participatory Rural Development (PRD) also called by someone as community driven development or community participatory development (Stohr, 1981) is an approach for more accountable governmental and increase poor people participation. Decentralization

Corespondence concerning to this article should be addressed to: onlyshakil@gmail.com is widely used concept now a days and policy makers applied this concept for the promotion of the development. It has increasingly been promoted as major component of the poverty alleviating strategies.

Most of the developing nations are still struggling for efficient use of their resources. In order to overcome physical and administrative constraints of the development, it is necessary to transfer the power from the central government to local authorities. Distribution of power from improves the management of resources and community participation which is considered key to sustainable development (Manor, 1995; Vaughan et. al. 1980, Mills et. al. 1990). Donor organizations, nations and international development institutions significantly shifted their attention from urban-industrial development and focus on rural participatory development. According to Kliksberg (1994), decentralization 

the term "Decentralization", got different meanings in different era's and fields and academics are not agree on proper use of this term (Smith, 1985). Thus decentralization can be referred as the transfer of authority to the linked lower hierarchy, whether the lowers tier related to local government or to some big organization. In contrast, Morgan (1986), a management scientist emphasis the decentralization as an organizational principle for divisionalised organization, but normative values for decentralization are different. There is functional, deconcentration/devolution dichotomy, political elite power administrative decisions and tetorrial decentralization. According to Guzman (1988), decentralization refers to the systemic sharing and dispersal of state government power. It's about delegation of authority to local level institutions, involving all the stockholders to come together as close as possible to problem area thus allow multi-sector decision making.

\section{Administrative Decentralization or Deconcen- tration}

Deconcentration refers to the simple dilution of centrality by distributing various elements of political and administrative activity to non-central offices. With deconcentration (also known as 'administrative decentralization'), strong centralizing tendencies coexist with particular forms of bureaucratic decentralization (Hoshino, 1994). It is a means of increasing central control. Many writers, for example Heager, are critical of the deconcentration approach to decentralization. He considers, deconcentration as a method for the central government to increase its power by more effectively curbing liberties" (Heager, 1974).

Manor (1995) is also critical of deconcentration when he says indeed, it is often used as a device used by the government for better control over lower level. But sometimes a greater degree of deconcentration is achieved through field administration by transferring them power to plan, decide and implement with in the boundaries set by central ministries. The power of field administrators, as Smith (1985) stresses, is 'bureaucratic rather than political.

\section{Functional Decentralization or Delegation}

Functional decentralization is also deconcentration to parasitical agencies with some financial and administrative separation from the main bureaucratic hierarchies (Manor, 1995; Hoshino, 1994). Delegation implies the lending of central authority, responsibility, and resources for exercising administrative and substantive functions to subordinate units or organizations in the centre. Although these organizations and agencies have been decentralized, they really serve to reinforce centralization and decision-making at the higher levels. The relative autonomy of these agencies, and their bureaucratic way of assuming certain functions and responsibilities, have given rise to serious problems of coordination and control (Harris, 1983). Delegation of function represents a more extensive decentralization than administrative deconcentration (Rondinelli, 1981).

\section{Political/ Democratic Decentralization or De- volution}

Transfer of resources, activities and power to decide for local development and division of tasks from the central government to lower authorities is called devolution. In devolution the lower authorities work as an autonomous body, independent from central government. Devolution implies more permanent and inter-governmental transfers, from national to local governments, of political as well as administrative and technical functions, answerable to the local community as a whole (Manor, 1995). The local government may challenge the central government's mandate, as asserted by Mrs. Thatcher, when she states that: "the hard left power was entrenched in three institutions: the Labor Party, local government and the trade unions (Thatcher: 1993 quoted in Pycroft, 1995).

The transfer of power to geographic units of local government that lie outside the formal command structure of the central government'. Thus devolution represents the concept of separateness, diversity of structures within the political system as a whole (Sherwood, 1969).

\section{Privatization}

It connotes the transfer of responsibility and resources for certain governmental functions to the private sector. Through privatization, governments divest themselves of responsibilities either by transferring them to voluntary organizations or by allowing them to be performed by private business. It is a recent fash- 

developing world, participation of communities in development process is considered as a basic element for good governance resulting accountability of government and benefit to poor peoples (World Bank, 1994).

\section{Nature and Definition of Participation}

\section{a) Defining Participation}

Participation has been defined in narrow and broad terms. In its narrow connotations, participation is defined as the active engagement of citizens with public institutions, an activity which falls into three well-defined modes: voting, election campaigning and contacting or pressuring either individually or through group activity, including non- violent protests (Verba et al., 1980; Parry et al., 1992). Excluded in this definition are attitudes towards participation and participation in rural development efforts. In its broad terms, participation is a "collective sustained activity for the purpose of achieving some common objectives, especially a more equitable distribution of the benefits of development" (UNESCO, 1979).

Political participation has been an issue in development management from the beginning, but its significance has increased principally because it has become part of official rhetoric. Individual full participation in making societal choices and decisions is a natural outcome of the endowment of individual dignity because it contributes to individual self- development. Responsibility for the governing of one's own conduct develops one's dignity. In particular full individual participation within the local institutions contributes to the creation of community solidarity because everyone feels involved in what is going on relative to their welfare (Uphoff, 1986).

Although there are different ways to define participation, the dominant perspective is to treat it pragmatically and to view it as a strategy to improve the development process.

\section{b) Changes in the Meaning of Participation}

Participation was considered and defined in terms of politics during late 1960's. It was only considered as people participation in vote casting, become a member of party and volunteer in some association. But with modernization in world, involvement of public is considered important for development. In the mean time, autonomous public organizations provided the channels for active community participation. Political parties are forced to consider public as asset and their demand should be given privilege (Parry, 1992).

"During implementation, individuals and groups have different motives and interests that might be conflicting and they compete to secure limited available resources. Limited resources and scarce funds leads towards poor development and suffer governmentpeople interaction" (Grindle, 1980). Similarly according to Lele "self confidence and self-reliance gained by rural community during planning and implementation of the projects is very important to keep development process effectively" (Lele, 1979). An influential statement by learning group of World Bank regarding participation is as under

"Participation is an activity in which development process is shared, influenced and controlled by stakeholders and two factors which affect them are decision and resources" (World Bank, 1994).

\section{Dimensions of Participation}

Participation is a very broad concept, and when the term is used in the context of development activities the question is how to operationalise that participation? The clear answer to this question demands familiarity with i) what (activities), ii) who (elites /ordinary people), and iii. How (the way /method of peoples' involvement) dimensions of participation. The 'what' dimension of participation consists of the various activities where people may participate? The report of the United Nations (1975) and other development studies revealed that people should participate in development projects from needs identification to needs satisfaction stage, only then can them are benefited from the development project. It implies the involvement of people in goal setting, planning, formulating, implementing and evaluating of development projects. According to Cohen and Uphoff (1980), people's participation includes a participation in decision-making and participation in Program implementation and evaluation.

The second dimension is a focus on who participates in a truly participatory approach those entire affected have to play a role at all stages of the development process (Lane, 1995). Cohen and Uphoff identified two groups of participants, residents and leaders, as particularly important in participation in development. The World Bank approach to the 'who' dimension of partici- 
pation calls for the participation of 'stakeholders'. The Bank defines stakeholders as the parties who either affect or are affected by development actions, which either have no power or lack information thus excluded from developmental process (World Bank, 1994).

The third dimension of participation is its organizational imperatives. The commentators and practitioners in development pleaded for participation through local organizations. The democratic, accountable and responsive organizations and associations including village councils, progressive unions, farmer's societies, traders associations and multi- purpose co-operatives, may be effective in participatory development (Verhagan, 1980).

The focus of 'how' dimension of participation is also on the degree or level of participation - the degree of empowerment. In his World Bank Discussion Paper, Samuel Paul identifies four methods of participation i.e. share information with whole community, consult for better understanding, participation in decision making and initiating actions for better proactive development (Paul, 1987). Latter indicates participation of the highest intensity. Each level of participation is characterized by a different relationship between the implementing agency and the beneficiaries. Information sharing participation refers to a process where the agency informs intended beneficiaries about the project, and so flows of information and control are both in downward direction. In a process involving consultation information flows are more equal, with the agency often making use of local knowledge; however control is still from the top down. In decision-making participation beneficiaries have some control over the process. Finally where participation has advanced to the stage of the beneficiaries initiating action both information and control flows are primarily upward, from the beneficiary group to the agency, but the donor agency retains some degree of control. According to World Bank, following are the measures which should be taken to improve the participation. These measures involve six mechanisms whose influence on stakeholders is from bottom to up. Theses includes following

1. Methods for information sharing among community and government

2. For better understanding consultation mechanism should be preferred

3. Appraisal Mechanism

4. Participatory decision making methods

5. Collective action for better development

6. Community empowering methods (World Bank, 1994).

Arnstein (1969) long ago considered peoples' participation as a categorical term for people power. According to her, it denotes nothing less than a redistribution of power that enables have-nots to share in the benefits of society.

Figure 1. Arnstein's Ladder of Citizen's Participation

\begin{tabular}{|c|c|c|c|}
\hline 8 & | & Citizen Control & degrees \\
\hline 7 & | & Delegated power & of \\
\hline 6 & | & Partnership & citizen \\
\hline 5 & | & Placation & power \\
\hline 4 & | & Consultation & degrees \\
\hline 3 & | & Informing & of \\
\hline 2 & | & Therapy & non- \\
\hline 1 & $\mid$ & Manipulation & participation \\
\hline
\end{tabular}


She proposes an analytical ladder of people's as shown in Figure-1. The classificatory principle in Arnstein's ladder is the amount of people power exercised. She presented her ladder of participation in graphic with the least desirable element first and the most desirable element last

\section{Participatory Approaches to Rural Development}

There are many obstacles to expand the citizen participation in rural areas. There are many approaches for participatory development but all have to face the same challenges. The concept of participation in the process of community development is far from new. Indeed, it was part of the rhetoric of the New Deal in the 1930s. It has become the dominating ideology in contemporary thinking in both non-governmental organization (NGO) and governmental / inter-governmental agencies (Poulton et al., 1988; Oakley, 1991 and Sadiullah, 2006).

"There are two main traditional approaches to rural participation: (1) community development programmes which were aimed at preparing the rural population to collaborate with government development plans; and (2) the establishment of formal organizations (cooperatives, farmers associations etc) which were to provide the structure through which the rural people could have some contact with, and voice in, development programmes" (Oakley and Marsden, 1984).

\section{Community Development Approach to Rural Par- ticipation}

The approach was based on development of capacity and self-reliance among community to participate for better development (Korten, 1990). There are good reasons for the close association of participation with a community development approach. First the aim to meet basic needs obviously requires the participation of all in benefits. Second, participation in implementation improves efficiency through the mobilization of local resources. 'Third, the development of a community's capacity to plan and implement change will require greater intensity and scope of participation as the project proceeds (Sadiullah, 2006) But Oakley and Marsden (1984) concede that the strategies developed had no meaningful impact on poor people and local community participation in development and the local elites continued to make and implement decisions in their own interests under the cover of a participatory organizational structure.

\section{Partnership Approach to Rural Participation}

A second general approach to participation can be distinguished from fostering people's organizations or promoting community-based activities. This approach attempts to create participatory partnerships rural development authority and governmental authorities for local development (Bergdall, 1993). Oakley and Marsdon (1984) have labeled this a 'collaboration' approach to rural participation where governmental or non- governmental organizations remain the primary driving force. Because decentralization programmes are an attempt to transfer specifically defined aspects of authority and control to District Councils or other local representative bodies. But many constraints, particularly ones of financial accountability and aid administration, make this a difficult task. In any case, as observers have noted, representative bodies remain just that:

"Participation becomes the prerogative of a privileged few who now find themselves included in a widening but nevertheless still quite small circle of decision-makers" (LaCompte, 1986).

\section{Obstacles to Participation}

All the developmental agencies in the world now discuss about the participative rural development approaches, including non-governmental organizations, governmental and inter-governmental agencies (Poulton and Harris, 1988; Oakley, 1991; Adnan et. al., 1992). The apathetic situation occurs mainly due to the poor economic, political and social position of people. But some times the latter they do not always want to participate. A recent Overseas Development Administration funded study observes that people feel that development functions were primarily the government's responsibility. Rather they prefer to participate passively and / or through their community leaders (quoted in Eyben and Ladbury, 1995).

Organization at village or even at district level is cither short or membership of poor people in such organizations is nonexistent. Hence local organizations easily become centers of formal power controlled by the few elites (Korten, 1981). 'The professional bureaucrats both at national and local level pose important barri- 
ers to effective local participation. Lack of community participation in projects can be the result of bureaucrats assuming the role of knowledgeable specialists who do not take user's views into account because users do not 'know enough' (according to them) to make decisions. However, some time the local people give their rights of decision to developmental professional thereby save conflicts, time and energy. Moreover the desire of participation is likely depend on the 'product' offered as much as on the development of channels and structures to make participation a practical possibility (Eyben and Ladbury, 1995).

\section{Conclusions}

Decentralization as a policy of rural development is consistently focused in many developing countries since the 1970s. The motivation for and application of decentralization policies varied considerably. In past deconcentration type of decentralization was favored in many countries. In a decentralized system, that stresses people's participation and devolution of authority, local units must be autonomous and clearly distinguished as a separate jurisdiction over which the centre exercises little or no direct control. In many of the cases the central governments initiated introduced and heavily publicized decentralization policies only to see them falter during implementation. Haque (1986) emphasizing the great extent of central control over local units as an "illusion of decentralization". The impact of decentralization varies from country to country; however, the results of decentralization policies so far implemented in developing countries are not impressive.

Development is a complex and continuous process, defined and interpreted in a variety of ways. Economists identify it with economic productivity and higher standard of living; sociologists with social change and social differentiation; political scientists with democratization and participation; and administration experts with bureaucratic performance. Underlying all these divergent viewpoints is common concern to improve the quality of life for man. Regardless of the efforts made by world from past generation, people still suffering for basic services. Almost one billion populations in the world still live the poverty line and have no access to education, health and clean drinking water.

\section{References}

1. Adnan, S. et al. (1992) 'People's Participation, NGO and the Flood Action Plan', Dhaka Research and Advisory Services

2. Arnstein, S. R. (1969) 'Ladder of Citizen Participation' Journal of the American Institute of Town Planning, Vol. 35. pp. 216-224

3. Bergdall, D. Terry (1993) 'Methods for Active Participation: Experiences in Rural Development from East and Central Africa' Nairobi: Oxford University Press

4. Cheema, G. S. and Rondinelli, D. A. (eds.) (1983) 'Decentralization and Development: Policy Implementation in Developing Countries' London: Sage

5. Cohen, John M. \& Norman T. Uphoff 1980 Participation's Place in Rural Development Seeking Clarity through Specificity. World Development 8:213-235.

6. Conyers, Diana (1983) 'Decentralization: The Latest Fashion in Development Administration' Public Administration and Development, 3 (2). pp. $91-110$

7. Conyers, Diana (1986) 'Future Directions in Development Studies: The Case of Decentralization' World Development, Vol. 15, pp. 593-603

8. Griffin, K. and Khan A. R. (1982) 'Poverty in Third World: Ugly Facts and Fancy Models' in Alvi, H. and Shanin, T. (1982) 'Introduction to the Sociology of Development of Societies' London: McMillan

9. Grindle, M. (1980) "Introduction," in M. Grindle (ed) Politics and Policy Implementation in the Third World, Princeton, N.J.. Princeton University Press

10. Guzman, R. P. (1988) 'Decentralization as a Strategy for Redemocratization in the Philippine Political System' Philippine Journal of Public Administration Vol. XXXII, No. 3\&4, pp. 217-225.

11. Harris, R. L. (1983) 'Centralization and Decentralization in Latin America' in Cheema, G. S. and Rondinelli, D. A. (eds.)

12. Hoshino, C. (1994) 'Land Development; Processes and Decentralization in Latin American Large Cities and Metropolitan Areas: Issue, Trends, and Prospects' Regional Development Dialogue, Vol. 15, No.2, pp. 29-60 
13. Kliksberg, B. (1994) 'The Necessary State: A Strategic Agenda for Discussion' International Review of Administrative Sciences, Vol. 60, pp. 183- 196

14. Lane, J. (1995) 'Non-Governmental Organizations and Participatory Development: The Concept in Theory verses the Concept in Practice' in Nelson, N. and Wright,S. (eds.) 'Power and Participatory Development: Theory and Practice' London: Intermediate Technology Publications

15. Lele, Uma (1979) 'The Design of Rural Development: Lessons from Africa' Baltimore: Johns Hopkins Press

16. Mabogunji, A. L. (1980) 'The Development Process: A Spatial Perspective' London: Hutchinson

17. Manor, J. (1995) 'Democratic Decentralization in Africa and Asia' IDS Bulletin, Vol. 26, No. 2, pp. 8 $1-88$

18. Morgan, G. (1986) 'Images of Organization' Newbury Park (Calif.): Sage

19. Mills, A; Vanghan, J. P; Smith, D, I. and Tabibzadeh, L. (1990) 'Health system decentralization: Concepts, Issues and Country Experience' Geneva: W. H.O

20. Oakley, P. et al. (1991) 'Project with People: The Practice of Participation in Rural Development' Geneva: ILO

21. Parry, G., Moyser, G. and Day. N. (1992) Political Participation and Democracy in Britain, Cambridge. Cambridge University Press

22. Paul, S. (1987) 'Community Participation in Development Projects: The World Bank Experience', in Reading in Community Participation. Washington, D.C: The World Bank

23. Poulton, R. and Harris, M. (1988) 'Putting People First: Voluntary Organisations and Third World Development’ Basing stoke: Macmillan

24. Rondinelli, D.A. (1981) 'Government Decentralization in Comparative Perspective in Developing Countries' International Review of Administrative Sciences, Vol. 47, No. 2, pp. 133-145

25. Rondinelli et.al (1989) 'Analysing Decentralization Policies in Developing Countries: A PoliticalEconomy Framework' Development and Change. Vol.20. pp. 57-87

26. Rondinelli, D.A. (1990) 'Decentralization, Territorial Power and the State: A Critical Response' Development and Change, Vol. 21, pp. 491 -500
27. Sadiullah, Khan. (2006) 'Local Government and Participatory Rural Development ': Gomal University

28. Sandstrom, Sven (1994) 'Poverty Reduction: Learning the Lessons of Experience' Finance and Development. September 1994, pp.30-33

29. Sherwood, F. P. (1969) 'Devolution as a Problem of Organizational Strategy' in Daland, R. T. (ed) 'Comparative Urban Research: The Administration and Policies of Cities' Beverly Hills: Sage, pp. 60-87

30. Smith, B. C. (1985) 'Decentralization: The Territorial Dimension of the State' London: George Allen and Unwin

31. Stohr, W. B. and Frases-Taylor, D.R. eds. (1981) 'Development From Above or Below? The Dialectics of Regional Planning in Developing Countries' Chichester: Wiley

32. Uphoff, N. (1986) Local Institutional Development: An Analytical Sourcebook, West Hartford, Kumarin Press.

33. Verba, S., Nie, N. M. and Kin, J. (1980) 'Participation and Political Equality: A Seven Nation Comparison' Cambridge: Cambridge University Press

34. Verhagan, K. (1980) 'How to Promote Peoples Participation in Rural Development Through Local Organizations' Review of International Cooperation, Vol. 73. No. 1

35. World Bank (1994) 'The World Bank and the Participation' Washington D.C: The World Bank

36. Werlin, H. H. (1992) 'Linking Decentralization and Centralization: A Critique of the New Development Administration' Public Administration and Development, Vol.12, pp. 223- 235 
